\title{
REHEARSALS FOR EMPLOYMENT: INDONESIAN SCHOOL KIDS ON STRIKE IN THE 1990s
}

\author{
Douglas Kammen
}

Strikes by high school students were a common feature of Old Order Indonesia. These "aksi," whether in response to problems within the school or to national political issues, helped define high school students (siswa) as part of the amorphous yet politically charged category "youth" (pemuda). But under the New Order "youth" has been all but expunged from the Indonesian vocabulary. ${ }^{1}$ In its place, school students are more likely to be called "pelajar" and "teenagers" (remaja) than "youth," more likely to be blamed for naughtiness than praised for social concern, let alone activism. ${ }^{2}$ Yet, over the past two years, while politicians debated the virtues of "openness" (keterbukaan), while university students protested the state-sponsored lottery (SDSB) and workers continued to strike for higher wages, junior and senior high school students have offered their own challenge: they too have gone on strike. ${ }^{3}$

This article has two goals: first, to illustrate a new, perhaps unsuspected, site of social unrest in contemporary Indonesia; secondly, I hope to offer a provisional argument that the origins of these strikes are intimately related to the ongoing labor unrest, and, by extension, the formation of a new proletariat.

\footnotetext{
1 The word appears most frequently now in reference to the 1928 Youth Pledge (Sumpah Pemuda) and in connection with the still active reactionary organizations that provided the storm-troopers of the 1965-66 anticommunist putsch, the members of which are now well into middle-age.

2 A recent edition the scholarly journal published by the Indonesian Institute of Sciences, LIPI, entitled "Young People and the Social Environment: Case Studies of High School Students in Several Cities," avoided both the words "pemuda" (youth) and the corresponding term "siswa" in favor of the politically neutral "pelajar." The question of student strikes was never mentioned. See Masyarakat Indonesia, X, 3 (December 1993).

${ }^{3}$ For the purposes of this article, high school students refers to both junior and senior high school students (SMP and SMA), both public and private. Reference to the few cases of strikes by elementary school students will be made explicit. Strikes are defined as collective refusals to attend class in order to protest school or local government policy. This rather narrow definition is employed in order to exclude both mass absenteeism and demonstrations in which high school students may participate but which are not directed at the school as an institution (e.g. the anti-SDSB demonstrations of 1993).
} 


\section{Students and Their Grievances}

Over the past several years the number of strikes by high school students has risen sharply. ${ }^{4}$ Between 1987 and 1991, there was an average of three strikes per year by high school students. This rose to thirteen cases in 1992, and further increased to thirty in 1993. The majority of these cases occurred at the beginning of the academic year-from September to November. While the eleven cases recorded through the first half of 1994 appear quite high, relatively few cases were reported in the press for the second half of the year. ${ }^{5}$

What is it, then, that Indonesian students are so upset about that they feel the need to strike? There are in fact six primary reasons students strike: first, to protest the quality of education in their schools; second, to protest school regulations ranging from bans on perfume to regulations on hair-length; third, to protest the innumerable fees levied by the school'; fourth, to protest the embezzlement of school money and other corrupt activities on the part of school officials; fifth, to protest the firing or reassignment of teachers; and sixth, to demand the resignation or replacement of school principals.

Finally, there are several cases in which students have gone on strike for reasons beyond the immediate concerns of the school: twice in response to military intervention in school affairs, once to protest the selection of a village head.

Table 1. Causes and Demands of Primary School Strikes, 1987-94

\begin{tabular}{lcccccccc}
\hline Demand & $‘ 87$ & $‘ 88$ & $‘ 89$ & $‘ 90$ & $‘ 91$ & $‘ 92$ & $‘ 93$ & $‘ 94$ \\
\hline Quality of Education & - & 1 & - & 1 & - & - & 3 & - \\
School Regulations & - & 2 & 1 & 1 & - & 2 & 2 & 4 \\
School Fees & - & - & - & 1 & 1 & 3 & 11 & 3 \\
Corruption & - & - & - & - & 3 & 1 & 4 & 2 \\
Firing of Teacher & - & - & - & - & - & 2 & 5 & 1 \\
Demand Principal Fired & 1 & - & - & 1 & 1 & 2 & 6 & 1 \\
Other (Military, etc.) & - & - & - & - & 1 & 2 & 1 & 2 \\
\hline
\end{tabular}

Note: one strike may involve more than one demand.

But if students are driven to strike for concrete reasons, their demands are not always taken as constructive criticism. More often than not school officials who find their authority challenged and government officials (ranging from those in the Department of Education to the local police and military) do their best to belittle student demands. Officials commonly argue that high school students on strike are only imitating the demonstrations frequently

4 The material for this article has been gathered from various newspaper and magazine articles. The following collections have been particularly useful: the Center for Strategic and International Studies (CSIS) in Jakarta, Kompas (Jakarta), and Surya (Surabaya).

I do not claim that these statistics are complete, merely that they provide an indicator of strike activity among school students. Unfortunately the Department of Education and Culture (Departemen Depdikbud) does not compile data on student strikes (or so they claim).

5 No data is available for 1995.

6 These fees include, among others: tuition (uang SPP and uang BP3), student association fees (uang OSIS), building fees, laboratory fees, special activity fees, book fees, and fees for nationally required tests. For a critical discussion of the problem, see "Pungutan di sekolah apa perlunya?" in Majalah Hai, February 9-15, 1988, pp. 6-9. 
staged by university students. ${ }^{7}$ Possibly. But if, by going on strike, high school students are merely imitating university student demonstrations, one would expect such strikes to be commonplace in the major university towns-Bandung, Yogya and Solo. They are not. ${ }^{8}$

It is also common for school principals, officials in the Department of Education and Culture (Departemen Pendidikan dan Kebudayaan), and the security forces to blame these strikes on the involvement of "third parties." In response to the rash of student strikes in 1993, the head of the East Java Department of Education and Culture first stated that "demonstrations are good," but went on to caution that "[t]here are indications that these demonstrations are being engineered." 9 The following exchange, in this case between the principal and students at High School 1 in Banjarmasin, is typical: "Children! This protest must have been organized by some rogue who doesn't like my presence here." The students yelled back "No, no," to which the principal responded: "You cannot do this. This [strike] is harmful to us and the state." 10

In a number of cases, school teachers have demonstrated along with their students, and may, indeed, have encouraged the action from the start. Elsewhere, parents may be responsible. There can be little doubt that parents are responsible for the strike by elementary school students at the Lapataman Elementary School in Sumenep, Madura, where the students protested the appointment of a new village head. ${ }^{11}$ But after all the accusations, officials generally concluded that "thus far there are no signs that the strike was orchestrated by outsiders." 12

\section{Geography of Student Strikes}

While the frequency of strikes by high school students has risen dramatically over the past two years, these actions have not been distributed evenly throughout Indonesia. Rather, these strikes are centered in particular areas. Of the eighty-four cases recorded between 1987 and 1994, the majority have occured in East Java, followed by the Greater Jakarta region (Jabotabek). The remainder are found in West Java (Cianjur, Tasikmalaya, Cirebon and Bandung), Central Java (Karanganyar, Magelang, Kudus, Semarang), and the outer islands (Samarinda, Banjarmasin, South Sulawesi, and Medan). (See Table 2.)

Are the problems which prompt high school students to strike-unreasonable regulations, school fees, corruption, firings-limited to particular regions? Not likely. Or is there something about East Javanese culture that explains why students in East Java are more critical than their age-mates elsewhere? There is, to be sure, a common perception that the east Javanese are more outspoken than the central Javanese; but they are certainly no more so than Bataks, Bugis, or a host of other ethic groups. Or should we, perhaps, look elsewhere for an explanation?

\footnotetext{
7 See the editorial "Unjuk Rasa Murid SD," in Jawa Pos, November 19, 1993.

8 Precisely because I had not found a single strike by primary school students in any of these cities, I interviewed a number of people in Bandung and Yogya. No one had ever heard of a single case occurring in Yogya, and only one case was reported for Bandung. I am grateful to Benny Hirawan for this information.

9 "Kakanwil Depdikbud: aksi unjuk rasa pelajar itu baik," Surya, September 23, 1993.

10 "Siswa SMAN 1 Banjarmasin unjuk rasa," Surya, September 19, 1992.

11 "Tak Setuju Kades baru Murid SD Lapataman 'Ngambek,'" Surya, February 20, 1992.

12 "Tak Ada Yang Mendalangi: Unjuk Rasa Yang Dilakukan Siswa SMA 1 Bojonegoro," Jawa Pos, September 26, 1993.
} 
Table 2. Regional Distribution of School Strikes, 1987-1994

\begin{tabular}{lcccccc}
\hline Year & $\begin{array}{c}\text { Greater } \\
\text { Jakarta }^{\text {a }}\end{array}$ & $\begin{array}{c}\text { West } \\
\text { Java }\end{array}$ & $\begin{array}{c}\text { Central } \\
\text { Java }\end{array}$ & $\begin{array}{c}\text { East } \\
\text { Java }\end{array}$ & $\begin{array}{c}\text { Outer } \\
\text { Islands }\end{array}$ & Total \\
\hline 1987 & 1 & - & 1 & - & - & 2 \\
1988 & 3 & - & - & - & - & 3 \\
1989 & - & - & - & - & 1 & 1 \\
1990 & - & - & 2 & 3 & - & 5 \\
1991 & 3 & - & 1 & 2 & - & 6 \\
1992 & 1 & 3 & - & 8 & 1 & 13 \\
1993 & 4 & 1 & - & 20 & 5 & 30 \\
1994 & 8 & 3 & 3 & 8 & 2 & 24 \\
Total & 20 & 7 & 7 & 41 & 9 & 84 \\
\hline
\end{tabular}

a. Includes Jakarta, Bogor, Tangerang, and Bekasi.

b. Includes Yogyakarta.

There is, in fact, another, even more surprising, geographic factor: over the past two and a half years, strikes by high school students have been most common in industrial centers and areas in which worker strikes are found. Of the eleven cases of student strikes between 1987 and 1990, only one occurred in a predominately industrial region. ${ }^{13}$ But as the current wave of industrial strikes began to spread in the early 1990s, so too did the incidence of student strikes. These cases, unlike their predecessors, were concentrated in and around industrial centers.

Two of the five cases of student strikes in 1991 took place in Tangerang, the birthplace of the current labor unrest. At SPM Yuppentek III, Balaraja, 150 students with placards in hand demanded the principal be fired. ${ }^{14}$ Similarly, at SMA 2, Tangerang, 275 striking students demonstrated at the Tangerang legislature (DPRD), demanding the school principal be replaced. ${ }^{15}$ The following year, 1992, precisely at the moment industrial strikes spread throughout the greater Jakarta and Surabaya areas, students staged four strikes in Surabaya, one in Malang, and another in heavily industrial East Jakarta.

The concentration of student strikes in industrial regions was even more dramatic in 1993. All of the cases in the greater Jakarta area and West Java took place in industrial centers. In February, six hundred students at the Sukatani High School in Bekasi went on strike to protest the embezzlement of student donations for the construction of a mosque. ${ }^{16}$ At the beginning of the academic year, hundreds of students at the St. Antonius High School in Karawaci, Tangerang, struck, demanding the principal be fired for hitting students. ${ }^{17}$ In November and December, hundreds of students at St. Antonius High School in heavily industrial East Jakarta struck twice to protest the dismissal of the principal and several of their favorite teachers. ${ }^{18}$ And in Cirebon, West Java, a hotbed of industrial and

13 This strike was at SMA 84 in West Jakarta. See "Kini Punya Harapan Baru," Majalah Hai, no. 52, December 29, 1987, pp. 4-5.

14 See, "150 Pelajar STM Unjuk Rasa Minta Kepsek Diberhentikan," Pos Kota, October 26, 1991.

15 "Gejolak di SMA 2 Tangerang," Majalah Hai, no. 51, December 17, 1991, pp. 74-77.

${ }^{16}$ Media Indonesia, February 17, 1993.

17 "Pak Guru, Dengarlah," in Editor, September 30, 1993.

18 "Ratusan siswa mogok belajar protes gurunya diberhentikan," Pos Kota, December 4, 1993. 
transportation strikes, eight hundred students at High School 4 struck. One poster summed up their demand: "Either the principal leaves or we do."19

The pattern repeats itself in East Java. During 1992-93 there were fourteen strikes at primary schools in Surabaya. Among these, two occurred at high schools (SMAN 10 and SMA 14) located a stone's throw away from the Rungkut Industrial Estate, the largest-and most frequently struck-industrial estate in East Java; another occured at SMEA PGRI 2 in the densely industrial and strike-prone region bordering Gresik. ${ }^{20}$ It should come as no surprise that, after witnessing workers' strikes on their way to and from school, school kids would finally realize that they need not simply accept (nerimo) unreasonable treatment. Like workers, students have found recourse for their grievances.

The connection between strikes by high school students and workers is not limited to major urban centers. In April 1993, as Malang was rocked by a series of major strikes by workers in the cigarette industry, hundreds of students at a junior high school in Malang went on strike. ${ }^{21}$ Not long after a series of industrial and transportation strikes in Pasuruan, hundreds of students at High School 2 struck demanding improvements in the quality of education and demanding that the principal be fired because of corruption. The students' posters included the combined accusation and threat, "Shave Mr. Nyatno bald," "This Is a School Not a Prison," and the blunt "Retire, Old Man."22

Other cases, although not in industrial areas, are nonetheless still connected with worker strikes-the increasingly frequent strikes by workers in the transportation sector. In Bojonegoro, hundreds of students at High School 1 went on strike on September 15, 1993 to protest corruption of school funds by the school principal. ${ }^{23}$ This occurred precisely at the time a flyer was circulating urging transport workers to strike in protest over the new traffic laws that were to go into effect on the September $17 .{ }^{24}$ In Madiun, two days after a strike by public transport drivers, nine hundred students at High School 3 refused to attend classes in protest over increased school fees, both legal (tuition, uang SPP) and extra-legal (pungutan liar). ${ }^{25}$ The story is much the same in Banyuwangi, where three hundred students at Genteng High School 1 followed in the footsteps of striking public transport drivers. ${ }^{26}$ Several months later, students at the Eka Lokasari Junior High School struck to protest the

19 "Tuntut Kepala Sekolah Mundur: Ratusan murid SMAN Cirebon masih melakukan unjuk rasa," Pos Kota, November 17, 1993; "Kembalikan guru kami," Harian Terbit, November 19, 1993.

20 For the strike at SMEA PGRI 2, see "Siswa bersama guru SMEA PGRI-2 unjuk rasa," Surya, October 8, 1992, and "Kepala SMEA PGRI 2 Lidah Wetan Diganti," Surya, October 9, 1992; for the strike at SMA 10, "700 Siswa SMAN X lakukan unjuk rasa," Surya, August 23, 1992; for the strike at SMA 14, "Tuntut Guru Lunak, Siswa SMAN 14 Unjuk Rasa," Jawa Pos, September 21, 1993.

21 Surya, 1993.

22 "Unjuk rasa murid SMAN 2 Pasuruan menuntut perbaikan mutu sekolah," Surya, October 22, 1993; "Ratusan Siswa SMA 2 Mogok dan Unjuk Rasa," Jawa Pos, October 22, 1993.

23 "Brutal, Unjuk Rasa SMA I Bojonegoro," Surya, September 16, 1993, and "Kepsek SMAN 1 Bojonegoro akhirnya mengundurkan diri," Surya, September 19, 1993.

24 The bulletin was issued by a group calling itself the Committee for Solidarity with the Indonesian Workers Struggle. See "Buletin anti UULLAJ beredar di Bojonegoro," Surya, September 1, 1993.

25 The strike at High School 3 is reported in Surya, "Kreatifitas dikebiri, siswa SMAN 3 Madiun unjuk rasa," November 4, 1993, and "Siswa menggelar protes ke-2 kepsek penuhi tuntutan siswa," November 5, 1993; for the transportation strike, see Jawa Pos, November 2, 1993.

26 "Ratusan siswa SMAN 1 Genteng tuntut sumbangan pembangunan dihapus," Surya, November 17, 1993. 
proposed school closing. Their banner read: "We may only be children of plantation workers, but we still need education." 27

What, then, of the cases in places such as Tuban, Jember, and Bangkalan, which are neither major industrial centers nor have experienced transportation strikes? It should, I'd suggest, come as little surprise that students who live in non-industrial areas are still affected by the news of worker strikes. They may hear stories first-hand from-or aboutrelatives working in the factories of Sidoarjo or Gresik, Tangerang or Bekasi.

Nor should we underestimate the role of the media, newspapers in particular. Over the past two years, the Indonesian press has been full of reports of protests (the anti-SDSB demonstrations, for example) and the ever-spreading industrial strikes. The newspapers circulating in the smaller cities of East Java (Tuban, Jember, and so on) are from and report on events in and around Surabaya. Television may exert no less important an influence. In three school strikes, students have demanded that their "McGyver"-a popular American television star and an affectionate nickname for favorite teachers-not be fired. In another popular American television series, "Beverly Hills 90210," the high school students staged their own strike. Cities like Kediri and Probolinggo, Sukoharjo and Wonogiri-all of which experienced student strikes in 1994-may be a far cry from Beverley Hills, but the assembly lines of mass culture's mass productions are ever so close to home.

High school students may, furthermore, be learning from workers' experiences and adopting similar tactics. In early 1994, high school students in Porong, Sidoarjo-the village where Marsinah worked and was murdered for leading a strike-went on strike. Like their siblings in the factories, the students demonstrated in front of the local legislature (DPRD). ${ }^{28}$ In Serang, striking students and teachers at the Serang PGRI High School demonstrated at the Serang legislature (DPRD). ${ }^{29}$ This tactic, also common among factory workers, may be employed less in the belief that local legislators will actually take action than as means of avoiding local military intervention. ${ }^{30}$

It is, therefore, difficult to avoid the conclusion that the recent spate of student strikes is intimately related to the ongoing worker unrest in Indonesia. Choking on Pancasila Moral Education (Pendidikan Moral Pancasila), students are learning from their brothers and sisters in the factories-leaving their benches to demonstrate in schoolyards and, more recently, in the streets. Lest one be misled by the terms, it should be remembered that the students on strike are not necessarily any younger than the factory workers on strike. ${ }^{31}$ And as the rapidly expanding educational system continues to produce far more graduates than there are jobs, more and more junior and senior high school graduates-particularly those in rural and industrial areas - are faced with the prospect of entering the industrial workforce.

In the final analysis, there is no better conclusion than that offered by Vivi I. Puspasari, a student at the Diponegoro Christian High School in Blitar, East Java:

Demonstrations are not destructive, but rather a constructive form of social control. Strikes by school students destroy the myth that students are lazy, spoiled, apathetic,

27 The original Indonesian read: "Meskipun kami anak karyawan perkebunan, tapi kami butuh sekolah." See "Siswa SMP unjuk rasa, 16 guru undurkan diri," Surya, April 19, 1994.

28 Suara Pembaruan, January 18, 1994.

29 “Pelajar dan guru STM PGRI unjuk rasa ke DPRD Serang,” Pos Kota, June 1, 1994.

${ }^{30}$ It is common for local police and military (Koramil and Kodim) units to handle such 'disturbances.'

$31 \mathrm{Up}$ to one quarter of the factory labor force in Indonesia consists of children under the age of seventeen. See "Jumlah Buruh Anak-anak Membengkak: Menaker Tutup Mata," in Jayakarta, June 5, 1993. 
and subservient. These strikes show that students' aspirations can not be corked up [disumbat]....

She goes on to place these questions within the broader context of political rights:

Attention must be paid to the interests, rights, and complaints of students. School regulations, even when made in the name of security and order, should not negate students' freedom. Teachers and principals can not be authoritarian or simply have their way.

And she concludes:

Viewing demonstrations as destructive is to only see their negative side. But if we view these demonstrations as a positive force, they appear as an antidote to a sick society. ${ }^{32}$

What Vivi, and scholars of Indonesia, need to consider is the possibility that the aspirations she so rightly argues cannot be ignored are the product of a particular, working-class environment.

32 Vivi I. Puspasari, "Demonstrasi Pelajar Sebagai media Konstruktif," in Jawa Pos, November 24, 1993. Emphasis added. 
